\title{
Evaluation of Public Policy of National Standard Education on Elementary School in Porong Sub-district, Sidoarjo District
}

\author{
Satunggale Kurniawan, Agus Sukristyanto, Endro Tjahjono \\ Doctoral Administration Study Program, 17 Agustus 1945 University of Surabaya, East Java, Indonesia
}

Email address:

satunggalek@gmail.com (S. Kurniawan)

\section{To cite this article:}

Satunggale Kurniawan, Agus Sukristyanto, Endro Tjahjono. Evaluation of Public Policy of National Standard Education on Elementary School in Porong Sub-district, Sidoarjo District. Journal of Public Policy and Administration. Vol. 4, No. 3, 2020, pp. $42-50$.

doi: $10.11648 /$ j.jppa.20200403.13

Received: July 21, 2020; Accepted: August 3, 2020; Published: August 31, 2020

\begin{abstract}
The purpose of this study is to analyze and explain the policy evaluation of the National Education Standards in Public Elementary Schools in Porong Sub-District, Sidoarjo District. Also, to analyze the factors that influence it and to formulate an evaluation model of National Education Standards in Public Elementary Schools in Porong Sub-District, Sidoarjo District. This research conducted using the Qualitative Description method. Data collection has done by observing activities at school, interviewing principals and teachers, and reviewing supporting documents. Then the data are analyzed interactively and tested the validity of the data by Triangulation. In this study used indicators of public policy evaluation, namely 1) Effectiveness, 2) Efficient, 3) Adequacy, 4) Responsibility, 5) Access, 6) Accountability. The results of the study showed that the National Education Standards applied by the State Elementary School in Porong Sub-District, Sidoarjo District was optimal. Several factors influence the application of National Education Standards, namely, 1) clear, smooth and careful communication; 2) Resources that can support education are fulfilled 3) Attitudes among school residents are good; 4) The bureaucratic structure in the education unit is clear and sequential. The researcher's suggestion for the school is to maintain the achievement of the National Education Standards in the school and need to innovate learning for students.
\end{abstract}

Keywords: Public Policy, Evaluation, National Education Standards, Curriculum

\section{Introduction}

The 1945 Constitution has mandated that the state is obliged to serve every citizen and population to meet their basic needs in public services and improve the welfare of the community. One form of service to the community is through the administration of education.

The performance of public services is still not as expected, so there are still many government services that have not been satisfactory and need to be improved. The cause of poor public service performance is because transparency and accountability have not been implemented in the implementation of public services yet.

The success of education can be seen in several aspects, such as the quality of education, educational equity, and education management. The Government established Government Regulation number 19 of 2005 concerning
National Education Standards as an effort to overcome the disparity in the quality of education in Indonesia. National Education Standards are a minimum criterion of the education system in the entire jurisdiction of the Unitary Republic of Indonesia, with 8 standards consisting of 1) Content Standards; 2) Graduates' Competency Standards; 3) Educator Standards; 4) Facilities and Infrastructure Standards; 5) Assessment Standards; 6) Process Standards; 7) Management Standards, and 8) Financing Standards.

From the purpose, National Education Standards have the function as a basis for planning, implementing, and supervising education in realizing quality national education, aiming to guarantee the quality of national education in educating the nation's population, forming the character and a civilization nation with dignity. Considering the importance of the National Education Standards for guaranteeing the quality of education for the life and quality of the nation's 
next-generation, it mandated that every education unit in the formal and non-formal channels must carry out the National Education Standards.

In recent times the problems that are happening at school become clearer. It turns out that implementing national education standards in Indonesia is not an easy matter. Some schools, educators, and education personnel have limited understanding and skills in applying standards. With the passage of policies to implement quality standards for educational resources does not develop by itself. The desired advantages need to be supported by skills in developing planning documents, data, evidence of the implementation of daily activities, as well as in the implementation of supervision that integrated into the system that has not reflected real action. Quality assurance becomes an essential issue in the implementation of activities in schools, so it must be supported by well-structured information and can be used as a basis for making quality improvement decisions.

Elementary Schools, as the level of education units in the education system in Indonesia, have a mission to give basic knowledge, attitudes, and skills for students. Therefore an evaluation mechanism is needed for the implementation of elementary schools by National Education Standards to achieve superior quality education.

So, this research also requires supporting data obtained from various literature, documents in the field, and information obtained directly from the principal and related parties. Thus, it can say that this study is original because it is very different from the various focus of previous studies.

\section{Materials and Methods}

\subsection{Public Policy}

Public policy is a science that stands alone, but in its application requires the involvement of other sciences, especially in social science. Therefore, if public policy not assisted by other sciences, both at the level of the concept and in its application will not work optimally. So, it is called a multidisciplinary science. According to Simon (2005: 23) said that the study of policy is called a field of study that can integrate with social sciences. Public policy also includes the process of forming a problem, how to solve it, how to determine the policy, how the policy is implemented and evaluated. Based on that reality, Thoha (2011: 105) says that many people interpret the public policy as the result of a government, state administration, and means to influence the results so that public policy is more defined as what is done by the government than how was the process. The brief review above signals that public policy is an act that is certainly not easy, especially because, in the end, public policy will set, control, and bind the public. As a product of public policy legislation, expected to be a means to ensure legal certainty and a sense of justice for the community, as well as protect the rights of citizens. To see the extent to which the policies made to solve the problem and which public policies made to achieve the desired results. In this case, this is to solve the problems that occur in the community. Therefore the criteria on which to judge whether the public policy has achieved the desired results have been determined.

\subsection{Policy Evaluation}

Policy evaluation is an activity that involves estimating or evaluating policies that include substance, implementation, and impact (Anderson: 1975). Policy evaluation, seen as a functional activity, it means that it is not only done at the final stage but rather to the entire policy process.

According to William Dunn, the term evaluation has a related meaning, each indicating several applications of scale values to policy and program results. Evaluation controlling several main functions in policy analysis. According to William N. Dunn, the evaluation function is: "First, and most importantly, evaluation providing valid and reliable information regarding policy performance. Second, evaluation contributes to the clarification and criticism of the values that underlie the selection of goals and targets. Third, evaluation contributes to the application of other policy analysis methods, including the formulation of problems and recommendations "(Dunn, 2003: 609 and 610). Evaluating a program or public policy needs criteria to measure the success of the program or public policy. There are evaluation criteria about the performance of policies in producing information as follows.

William N. Dunn mentioned several policy recommendation criteria that are the same as, the policy evaluation criteria, the policy recommendation criteria consist of (1) Effectiveness, which related to whether an alternative is achieving the expected results (results) or achieving the objectives of the action. This effectiveness is closely related to technical rationality that is always measured by the unit of product, service, or monetary value. (2) Efficiency relates to the effort needed to produce a certain level of effectiveness. Efficiency, which is a synonym of economic rationality, is a relationship between effectiveness and effort, generally measured by monetary costs. (3) Adequacy, which is related to how far the effectiveness of satisfying the needs, values, or opportunities to create problems. Adequacy criteria emphasize the strong relationship between policy alternatives and expected outcomes. (4) equity, this relates to legal, social rationality and refers to the distribution of the effects of effort between different groups in society. Equity-oriented policies are policies that affect (for example, service units or monetary benefits) or business (monetary costs) that are fairly distributed. Policies designed to distribute income, educational opportunities, or educational services are sometimes distributed based on the criteria for equality. The similarity criterion is closely related to competing concepts, namely justice and to the surrounding ethical conflicts that are sufficient to distribute the public's risk. (5) Responsiveness is related to how far a policy can satisfy the needs, preferences, or values of certain groups of society. Responsiveness criteria are essential because this can satisfy 
all criteria. Responsiveness criteria are essential because an analysis that can satisfy all criteria - effectiveness, efficiency, adequacy, equality -. It fails if it has not responded to the actual needs of the group. 6) Appropriateness is strictly related to rationality and substantive because the question of the appropriateness policies does not concern on individual units of criteria but two or more criteria together. Accuracy refers to the value or price of program objectives and the strong assumptions underlying these goals.

These criteria are benchmarks and indicators of evaluating public policy. Ripley (1986) in Purwanto 2012) also explains that various indicators used to assess the quality of policy outcomes are as follows. (a) Access, this indicator is used to know that the program or service provided is easily accessible to the target group. Also, access implies that people are responsible for implementing policies or programs that are easily contacted by the target group's people if they need information or want to submit complaints. (b) Coverage, it is used to assess how much the target groups have reached (for getting services, grants, transfers of funds, and others) by the implemented public policies. The procedure used to measure coverage is: 1) Define who is the target group (needy families, farmers, civil servants, and others.). Ideally, evaluators have data on all target groups who have the right (eligible) to become the target group. 2) Make a proportion (comparison) of the number of target groups that have received services to the entire target group; (c) Frequency is an indicator to measure how often the target group can obtain the services by a policy or program. If the frequency of services is getting higher, the implementation of a policy or program is getting better. Frequency indicators are critical and relevant to know the success of implementation or programs whose types of services not only given once, but repeatedly such as the RASKIN program (governmentsubsidized rice assistance for people in need), direct cash assistance, and supplementary feeding programs for children in schools. (d) Bias, which is an indicator used to assess whether services are provided by implementer bias (deviant) to groups of people who are not the target, or groups of people who are not eligible to enjoy assistance, grants, or services provided by the government through a policy or program. (e) Service delivery, an indicator used to assess whether the services provided, which are, the implementation of a program are carried out on time, or not. This indicator is significant for assessing outputs that have a time sensitivity; this means delays in program implementation will have implications for failure to reach the program. (f) Accountability, this indicator used to assess whether the actions of the implementers in carrying out the tasks to the target group can be accounted for or not. Important questions that need to ask are whether the target groups reduced or not. If there is a reduction in the rights of the target group, is this action accountable, or is it a deviation. (g) The suitability of the program with the needs, this indicator used to measure whether various policies or programs are by the needs of the target group.

\subsection{National Education Standard}

In Government Regulation No. 19/2005, the National Education Standards are the minimum criteria regarding the education system in the entire jurisdiction of the Unitary Republic of Indonesia. National Education Standards aim to ensure the quality of national education in the context of educating the life of the nation and forming the character and civilization of a dignified nation. The standard consists of eight points that must be owned and fulfilled by the organizers as well as education units in Indonesia.

The function of this national education standard is as a basis in planning, implementing, and monitoring education to realize quality national education. Meanwhile, national education standards aim to guarantee the quality of national education in the intellectual life of the nation as well as to create a civilized and dignified character. The function of this national education standard is as a basis in planning, implementing, and monitoring education to realize quality national education. Meanwhile, national education standards aim to guarantee the quality of national education in the intellectual life of the nation as well as to create a civilized and dignified character. The eight National Education Standards include: 1) Content Standards, this is about the minimum material and the minimum level of competence. This goal is to achieve minimum graduate competency at a certain level and also the type of education. This standard contains the basic framework, curriculum structure, learning load, education unit curriculum, and education calendar. 2) Process Standards, the Learning process in the education unit conducted Interactive, Inspirational, Enjoyable, Challenging, and also make students motivated to participate actively. This standard also provides sufficient space for the initiative, creativity, and also independence according to the talents, interests, psychological and physical development of students. However, the learning process must also include an exemplary element. 3) Graduates' Competency Standards; it used as a guideline for assessing graduation to students for primary and secondary education units. These standards include minimum competency for primary and secondary education units, minimum competency standards for subject groups and also minimum competency standards for subjects. 4) Education Standards and Education Personnel, educators must have academic qualifications and competencies as agents of learning, physically and mentally healthy and can realize the objectives of the national education. The intended academic qualifications are the minimum level of education that must be fulfilled by the educator and then proven by diplomas and certificates of relevant expertise by applicable laws. 5) Facilities and Infrastructure Standards, each education unit must have facilities which include educational facilities, books, and other learning resources. Each education unit must have facilities and infrastructure that includes area, classrooms, class unit leadership rooms, teaching rooms, administrative rooms, library rooms, laboratories, and other supporting rooms. 6) Education Financing Standards, education funding consists of operating 
costs, investment and personal costs. The education unit investment costs referred to include the cost of infrastructure, human resources development and permanent working capital while the personal costs in question are the education costs. It must be spent by students to be able to follow the learning process in a conducive, orderly and also sustainable manner. At the same time, the operating costs in question include salaries of teaching staff, education staff, and also benefits attached to salaries. Consumable materials and equipment as well as indirect education costs such as telecommunications, consumption and transportation costs. 7) Educational Assessment Standards, assessments at the level of primary education to secondary level consist of assessments of learning outcomes by educators, education units, and the government. While for higher education consists of assessments of educators and higher education units. 8) Management Standards, this standard is a standard that covers from the planning, supervision and implementation of education at the education level of Regency / City, Province, to the highest level, namely the national level.

\subsection{Framework of Thinking}

The government has the function of providing various public services that are needed and needed by the community, one of the government services in order to prosper the community through education. The government, as the person in charge of national education, has the right to formulate policies that become national priorities, especially those relating to the efficiency, quality, and equity of education. To overcome the problems of education that occur in various education units, the government has established Government Regulation number 19 of 2005 concerning National Education Standards. To streamline the research, the researcher evaluates three scopes of Standards; namely 1) Content Standards; 2) Process Standards; 3) Graduation Standards. It hoped that through the National Education Standards policy, each education unit can guarantee the quality of education and can improve the intellectual intelligence of students and build the nation's character. Government policies on National Education Standards need to evaluate, the aim being to evaluate the success and failure of these policies based on predetermined standards or criteria. The first task refers to trying to see whether the public policy program is achieving the desired goals or not. If not, what are the factors that cause it? The second task is policy evaluation which is closely related to the first and third tasks, namely formulating a policy evaluation model. To find out the results of the policy evaluation, is based on six criteria for policy evaluation, including 1) Effectiveness; 2) Efficiency; 3) Adequacy; 4) Responsibility; (5) Access; and 6) Accountability. It expected that the evaluation of the three Education Standards based on the six criteria for evaluation of the policy could produce good quality education.

\subsection{Research Methods}

This research uses descriptive qualitative research methods.
Djam'an Satori (2011: 23) revealed that qualitative research conducted because researchers wanted to explore phenomena that could not be quantified. This method is descriptive such as the process of a work step, the formula of a recipe, the notions of a variety of concepts, the characteristics of an item and services, images, styles, procedures for a culture, physical models of artefacts, and others. In this case, the researcher used a descriptive qualitative research method because this study explored an evaluation of the National Standards of National Elementary School Education in Porong Sub-District, Sidoarjo District. Also, this study is inductive, and the results emphasize more on meaning.

The focus of the research aims to limit researchers so that they are spared and not trapped in data collection in fields that are very general and broad or less relevant to the formulation of the problem and research objectives, namely: Porong Sub-District Sidoarjo District. In this case, the main concern is the application of Content Standards, Process Standards, and Graduates Competency Standards in which these three things become the first Standards in educational activities. The dimensions/aspects seen are a) Effectiveness Achieving the objectives set; b) Efficiency - Optimum use of resources; c) Adequacy - Can solve the problem; d) Responsiveness - Can satisfy the needs, preferences, or values of certain groups; e) Access - Right on target and easily accessible; f) Accountability - Can be responsible for policy outcomes. 2) Factors that support and hinder the National Education Standards in Public Primary Schools in Porong Sub-District, Sidoarjo District. The dimensions/aspects seen are a) Supporting factors, originating from the internal and external environment of the school; b) The inhibiting factors come from the internal and external environment of the school as well. 3) National Education Standards Evaluation Model in Public Elementary Schools in Porong Sub-District, Sidoarjo District. As for the dimensions/aspects seen: a) Evaluation Criteria used include Effectiveness, Efficiency, Adequacy, Responsiveness, Access, and Accountability; b) Factors that support and inhibit.

This research conducted in 3 Public Elementary Schools in Porong Sub-District, Sidoarjo District, those is Glagaharum Public Elementary School, Kebakalan Public Elementary School and Plumbon Public Elementary School. The subjects and informants of this study were the principal, deputy headmaster, and teachers in SDN Porong Sub-District, Sidoarjo District. The determination of subjects and informants based on that the principal, deputy headmaster and teachers are the authorities in implementing the National Education Standards.

Data collection methods are used by 1) Observation, which used is direct observation. The direct observation in this study used to reveal data regarding the implementation of the National Standards for Elementary Education in Porong SubDistrict, Sidoarjo District, which included Content Standards, Process Standards, and Graduates Competency Standards. 2) Interview, the type of interview used in this study is a structured interview. That is, in conducting interviews, the researcher has prepared an instrument of written questions. In 
this case, researchers conducted interviews with School Principals, vice principals, and teachers who implemented the National Education Standards. 3) Documentation, the documents used in this study are a list of research respondents, photos of the implementation of National Education Standards, and supporting documents for the implementation of National Education Standards-based on Content Standards, Process Standards, and Graduates Competency Standards.

The data analysis technique applied in this study is the Interactive Model. The steps taken by researchers by using an interactive model of qualitative analysis are: 1) Observe the activities of teachers in the implementation of National Education Standards. 2) Interview with the Principal who authorizes the National Education Standards according to the interview guidelines that have made. 3) Read and describe statements from the Principal and teacher, look for definitions and postulates that are suitable by noting essential matters relating to key concepts that have established in the form of statements, definitions, elements, and others. 4) Categorize the notes taken from the data source then classify them into the same category. 5) Categorizing the categories that have arranged and connected with other categories so that the results of the arrangement will be systematic and related to each other. 6) Analyze the relevance of data by examining the systematic arrangement of the talks and their relevance to the research objectives. 7) Completing data by reviewing data content in the form of observations, results of interviews, or results of documentation in the field. 8) The answers utilized it means that the results of the study data used as answers after being analyzed. 9) Prepare a report, after describing the answers in detail, then compile it in the form of a report. The data validity checking technique in this research is to use triangulation with the type of Triangulation Source. Source triangulation is to test the credibility of the data carried out by checking the data that has obtained through several sources. Triangulation of this source is used by researchers to check data obtained from the Principal and Teacher.

\section{Result and Discussion}

\subsection{The Description of the Policy Evaluation of National Education Standards}

Evaluation of National Education Standards for Elementary Schools in Porong Sub-District, Sidoarjo District provides maximum results. It can see from the Achievement of National Education Standards in each school. One of the main things in the National Standards is the application of the Curriculum, which in the three schools in Porong SubDistrict are both applying the 2013 Curriculum.

National Education Standards set as the minimum criteria in conducting education in all regions of Indonesia. National Education Standards as a basis for planning, directed and sustainable by the demands of local, national and global change. Evaluation and quality control of education by the
National Education Standards need to evaluate. National Education Standards evaluated in this study are 1) Content Standards, 2) Process Standards, and 3) Graduates Competency Standards.

\subsubsection{Effectiveness}

Effective is the achievement of results by the goals set, so that effectiveness shows success in terms of whether or not the target achieved. If the policy results are getting closer to the target, the higher the effectiveness. Assessment of effectiveness aims to answer the timeliness of achieving the results/policy objectives. Effectiveness in the policy's evaluation in question is the achievement of the 2013 curriculum's implementation, which seen from the timeliness of the suitability of the results with the desired goals. The opinion of the informant proves that the implementation of the 2013 curriculum in Glagaharum Elementary School has been effective. It is evident from the results of reports on daily Deuteronomy scores, Mid-Semester Assessment, and Final Semester Assessment of all students who have exceeded the Minimum Completion Criteria. Likewise, the Kebakalan Elementary School and Plumbon Elementary School have also implemented the 2013 Curriculum effectively. Of the three schools, the Curriculum that has determined for students implemented well, and students can show the results of learning activities by the specified time. Although students' learning achievements remedially obtained, they have been compiled in the Learning Implementation Plan so that all students can achieve the expected learning outcomes.

Based on the results of this study, the implementation of the 2013 curriculum seen the timeliness of suitability results with the desired objectives. The implementation of the 2013 curriculum at Glagaharum Elementary School has been effective. It is evident from the results of reports on daily Deuteronomy scores, Mid-Semester Assessment, and Final Semester Assessment all students have exceeded the Minimum completeness Criteria scores. Likewise, the Plumbon Elementary School of Kebakalan and Elementary School have also implemented the 2013 Curriculum effectively. Of the three schools, the Curriculum that has determined that students can implement properly and students can show the results of learning activities by the specified time. Even though the students' learning achievement obtained remedially, it has also been compiled in the Learning Implementation Plan so that all students can achieve the expected learning outcomes. It is consistent with Dunn's opinion, Effectiveness (Effectiveness) about whether an alternative achieved the expected results, or achieve the objectives of holding actions that are closely related to technical rationality. It always measured by the product unit, service or monetary value. (Dunn, 2003: 429). If after the implementation of public policy activities, the impact is not able to solve the problems faced by the community, then it can be said that a policy activity has failed. However, sometimes public policy results are not immediately useful in the short term, but after going 
through a specific process.

\subsubsection{Efficiency}

According to William N Dunn (2003: 430), which states that: "Efficiency refers to the amount of effort needed to produce a certain level of effectiveness. Efficiency, which is a synonym of economic rationality, is the relationship between effectiveness and effort, which is generally measured by monetary costs. Efficiency usually determined through the calculation of the cost per unit of product or service. Policies that achieve the highest effectiveness with the smallest cost are called efficient ". The application of the 2013 curriculum based on the results of the study was already effective. The availability of resources owned by Glagaharum Public Elementary School, Kabakalan Public Elementary School, and Plumbon Public Elementary School is adequate. With the existence of School Operational Assistance funds and added support from the school community, the Implementation of Educational Activities in the three schools has proven to be quite efficient. The researcher believes that in order to carry out any activities to achieve the expected results, adequate funding must be supported, likewise, in the implementation of this 2013 curriculum. Because funding is one of the resources in the application of management, without financial support, the policy will not be able to run optimally.

From the explanation of the research results, the application of the 2013 curriculum was already effective. The availability of resources owned by Glagaharum Public Elementary School, Kabakalan Public Elementary School, and Plumbon Public Elementary School was adequate. With the existence of School Operational Assistance funds and added support from the school community, the Implementation of Educational Activities in the three schools has proven to be quite efficient. The researcher believes that to carry out any activity in order to achieve the results they expect, adequate funding must be supported. Likewise, in the application of the 2013 curriculum, because funding is one of the resources that must exist in the application of management.

Effectiveness and Efficiency are closely related. When we talk about Efficiency when we imagine the use of our resources optimally to achieve a specific goal, the point is that Efficiency will occur if the use of resources is optimally empowered so that a goal will we achieve. Implementing a policy or any activity should be supported by adequate funding because every implementation of the activity does require financial support. Without adequate financial support, any activities will not carry out properly, and the results achieved will not be optimal.

\subsubsection{Adequacy}

Adequacy in policy can say that the objectives that have achieved are sufficient in various ways. William N. Dunn argues that adequacy is related to how far a level of effectiveness satisfies the needs, values, or opportunities that create problems (Dunn, 2003: 430). From the above understanding, it concluded that adequacy is still related to effectiveness, namely measuring or predicting how far that can satisfy the needs, values, or opportunities in solving problems that occur. From the results of the research, it is proven that the existence of the 2013 Curriculum both in Glagaharum Public Elementary School, Kebakalan Public Elementary School, and Plumbon Public Elementary School can provide significant benefits or influence, especially in the learning process. Also, support from the government must be ready in providing needs such as textbooks that can be used by every student in the learning process. Researchers believe that the 2013 curriculum can provide benefits or influence on the target group. Hence, the related parties, both local government (executive) and other parties, need to evaluate the policy's implementation.

Based on the research results, it is a proof that the existence of the 2013 Curriculum in Glagaharum Public Elementary School, Kebakalan Public Elementary School, and Plumbon Public Elementary School can provide significant benefits and influence, especially in the learning process. Also, support from the government which must be ready to provide needs such as textbooks that can be used by every student in the learning process. Researchers think that the 2013 curriculum can provide benefits or influence for the target group, so the related parties, both the local government (executive) and other related parties, need to evaluate the policy's implementation.

Adequacy in public policy can say that the goals achieved felt to be sufficient in various ways. William N. Dunn argues that adequacy is about how far a level of effectiveness satisfies the needs, values, or opportunities that create problems (Dunn, 2003: 430). Therefore, before a policy product is approved and implemented, there must be an analysis of the suitability of the method to be implemented with the objectives to be achieved. Whether the method is correct, the technical implementation is also correct or violates the rules.

\subsubsection{Responsiveness}

Responsiveness in policy can we interpret as a response from an activity-namely, responses to alternative policy targets for implementing a policy. According to William N. Dunn, responsiveness is about how far a policy can satisfy the needs, preferences, or values of particular groups of people (Dunn, 2003: 437). Based on research at Glagaharum Public Elementary School, the implementation of the 2013 Curriculum received an excellent response from the school and all students. We can see from the average student learning outcomes, and the school environment has shown an attitude that is in line with the vision and mission of the school. Likewise, with Kebakalan Public Elementary School and Plumbon Public Elementary School, they can also respond to all learning activities that are by National Education Standards. Even though the situation at Plumbon Public Elementary School blocked by mudflow, all schools and students can carry out the education policies that have set. This opinion proves that the implementation of the 2013 curriculum received an excellent response from the school 
and positive support from parties, including those involved in the learning process. To that end, researchers argue that the response of each involved in the learning process is excellent. However, some things must be completed by policymakers, namely, to pay attention to any advantages and disadvantages of policies issued.

\subsubsection{Access}

Access indicators used to find out that the program or service provided is easy to reach by the target group. Access also contains an understanding of the occurrence of equal opportunities for all target groups, regardless of individual characteristics or inherent groups, such as gender, ethnicity, religion, and political affiliation. Thus, access can also mean that there is no discrimination in engaging and enjoying the benefits of policies or programs because of individuals' or groups' inherent characteristics. Based on research, although the three schools in the Porong sub-district have been affected by the Lapindo Mudflow disaster, these schools can carry out educational activities well. We can see from the number of students in each school. Glagaharum Public Elementary School has 154 students, Kebakalan Public Elementary School has 126 students, and Plumbon Public Elementary School has 62 students. Plumbon Public Elementary School has the smallest number of students because it is the closest school to the mud embankment compared to other schools. Nevertheless, the three schools are still easily accessible both in accommodation and facilities and infrastructure. It has overcome by the government handling the impact of the Lapindo mudflow disaster and is trying to prevent the spread of the Lapindo mudflow impact.

From the explanation of the research results, although the three schools in the Porong sub-district have been affected by the Lapindo Mudflow disaster, they can carry out educational activities well because these schools are easily accessible both in terms of accommodation and facilities and infrastructure. According to Ripley (1986) in Purwanto (2012), access implies that people are responsible for implementing policies or programs easily contacted by the community. Also, be the target group of the policy or program, if they need information or submit complaints. Access also means equal opportunities for all target groups, regardless of individual characteristics or inherent groups, such as gender, ethnicity, religion, and political affiliation. Thus, access can also mean that there is no discrimination in engaging and enjoying the benefits of policies or programs because of the inherent characteristics of individuals or groups.

\subsubsection{Accountabilty}

Accountability, this indicator is used to assess whether the actions of the implementers in carrying out tasks to the target group can be accounted for or not. Accountability in question, that is, concerns whether the target group reduced or not. If the target group reduced, then this must be justified. The 2013 curriculum, which has been determined both in Glagaharum Public Elementary School, Kebakalan Public
Elementary School, and Plumbon Public Elementary School, is appropriate for students. Students at each grade level are also by their respective grade levels. All students can also achieve curriculum material at each grade level. Therefore the level of accountability of the 2013 Curriculum in the three Public Elementary Schools is high.

Based on research, the 2013 curriculum, which has been determined both in Glagaharum Public Elementary School, Kebakalan Public Elementary School, and in Plumbon Public Elementary School are appropriate for students. Students at each grade level are also by their respective grade levels. All students can also achieve curriculum material at each grade level. Therefore the level of accountability of the 2013 Curriculum in the three Public Elementary Schools is high. It is by the opinion of Ripley (1986) in Purwanto (2012), the Accountability indicator used to assess the actions of policy implementers in carrying out tasks to target groups that can be accounted for or not. So this concerns whether the target group reduced or not if there is a reduction in the target group's rights whether the action can be accounted for or is a form of deviation.

\subsection{Factors Affecting National Education Standard}

The factors that support and hinder the National Education Standards in Public Elementary Schools in the Porong Sub-District, Sidoarjo District are: (a) Communication. An educational policy can run well if there is excellent communication between policymakers, policy implementers, and the target parties Policy. Policy decisions and orders must be forwarded to the appropriate personnel before they can follow. The communication must also be clear, easy to understand, and careful by the implementers. Within the scope of education, communication must be established between the Education office, the school principal, staff, teachers, education personnel, and students; (b) Resources and Resources are an essential factor in education policy. Resources include a sufficient amount of staff and the right expertise to carry out tasks such as recording information, authority, and facilities needed to translate proposals into public services. The resources needed in the course of the National Education Standard include school principals, teachers, education personnel, funds, facilities, and infrastructure. (c) Attitude, The success of a policy is not only based on the ability of the implementers but also must be based on a good attitude among the parties concerned in carrying out a policy. (d) Bureaucracy, the policy has not been said to be useful if there is inefficiency in the bureaucratic structure in the education unit. The bureaucratic structure includes aspects such as the existing organizational structure and its relationship with outside the organization. Therefore, in each education unit, a school bureaucratic structure needs to be compiled, consisting of the education office, school principal, deputy headmaster, committees, teachers, education staff, and students. 


\subsection{National Education Standards Evaluation Model}

The explanation of the results of the research can formulate an Evaluation Model of the National Education Standards in Public Elementary Schools. The dimensions/aspects seen based on the following indicators: 1) Effectiveness, in the assessment of the Effectiveness of National Education Standards, can be seen from the Curriculum Arrangement and Learning Tools applied in schools. Then, it compared with student learning outcomes. If students show optimal learning outcomes, the National Education Standards at the school can assess as effective. 2) Efficiency, effectiveness, and efficiency are closely related. So, in addition to measuring efficiency and paying attention to the applied curriculum, also pay attention to the resources that can support the implementation of educational activities, namely funds, facilities, and infrastructure, as well as education personnel. 3) Adequacy, in evaluating the adequacy, National Education Standards can be considered from the benefits and effects of the curriculum applied to students and the school community. 4) Responsiveness, which needs to consider in assessing responsiveness, is that the 2013 curriculum received an excellent response from the school and positive support from all parties, including those involved in the learning process. 5) Access, in evaluating the National Education Standards, a school / educational unit must be easily accessible both in terms of accommodation and facilities and pre facilities. 6) Accountability, an education unit in assessing its accountability, must pay attention to the composition of the curriculum applied, whether by the conditions of students and the school community.

\section{Conclusion}

Based on the formulation of the problems raised, we can conclude that:

1. Evaluation of the policy for National Standards of Public Elementary School Education in Porong SubDistrict, Sidoarjo Regency to run optimally. It is demonstrated by the six indicators of policy evaluation, namely, the achievement of indicators of effectiveness and efficiency, the readiness of resources in each education unit has been evenly distributed, and all students have achieved the implementation of the 2013 Curriculum. Judging from the adequacy and Equity indicators of the implementation of the National Education Standards, complete facilities and infrastructure can support the implementation of education. Also, learning tools are by the 2013 Curriculum, and access to the National Education Standards means that students and the school community can easily access the education units. Also, accountability in the National Education Standards can be seen from the curriculum arrangements applied by the school environment's conditions.

2. The factors that influence the National Standards of Education are; 1) Communication between the education office, school principals, staff, teachers, and students established smoothly and accurately. 2) Resources, namely the qualifications of excellent educators and teaching staff, funds, facilities, and infrastructure. 3) Attitudes, between principals, educators, and education personnel, and students show a good attitude. 4) Bureaucracy, the structure of the bureaucracy in the education unit is clear and collapsed in each relationship.

3. The formulation of the National Education Standards Evaluation Model can review through several indicators, namely 1) Effectiveness. Assessment of the Effectiveness of National Education Standards can be seen from the Curriculum Arrangement and learning tools applied in schools compared with student learning outcomes. 2) Efficiency, in measuring efficiency in addition to paying attention to the curriculum used, also pay attention to resources that can support the implementation of educational activities such as funds, facilities, and infrastructure, as well as education personnel. 3) Adequacy, in evaluating the adequacy, National Education Standards can be considered from the benefits and effects of the curriculum applied to students. 4) Responsiveness and responsiveness assessment that needs to be considered is the 2013 curriculum, which received excellent responses from students. 5) Access, in evaluating the National Education Standards, a school / educational unit must be easily accessible in terms of accommodation and facilities and infrastructure. 6) Accountability, an education unit in assessing its accountability, must pay attention to the composition of the curriculum applied, whether by the conditions of students and the school community.

Suggestion

1. For schools, in order to maintain achievements and all educational achievements that are by National Education Standards.

2. Teachers must always innovate in learning activities while still paying attention to the established National Education Standards.

\section{References}

[1] Ahmadi and Syukran Nafis. 2011. Islamic Education Management. Yogyakarta: Laks Bang Presindo.

[2] Ara Hidayat \& Imam Machali. 2012. Education Management. Bandung: Kaukaba.

[3] Atmodiwirio, Soebagio. 2000. Indonesian Education Management. Jakarta: Ardadizyajaya.

[4] National Education Standards Agency. 2008. The Elementary Level Unit Education Curriculum. Jakarta: National Education Standards Agency. National Education Standards Agency. 2006. Regulation of the Minister of National Education of the Republic of Indonesia No. 22/2006 concerning Content Standards for Elementary and Secondary Education Units. Jakarta. 
[5] Ministry of Education. 2007. Law of the Republic of Indonesia Number 20 of 2003 concerning the National Education System. Jakarta: Cemerlang Publisher.

[6] Ministry of Education, Big Indonesian Dictionary Third Edition, Jakarta: Balai Pustaka, 2002.

[7] Dunn, William N. (2003). Public Policy Analysis. Yogyakarta: Gadjah Mada University Press.

[8] Hamalik, Oemar. 2007. Management of Curriculum Development. Bandung: PT. Remaja Rosdakarya.

[9] Isjoni. 2006. Education as a Future Investment. Jakarta: Yayasan Obor Indonesia.

[10] Kintamani, Ida Dewi Hermawan. 2010."Evaluation of National Standards Junior High School Program Based on National Education Standards"."Journal of Education and Culture". Vol. 17. No. 6: p. 619-634.

[11] Kurniadin, Didin and Machali, Imam. 2012. Education Management: Concepts and Principles of Education Management. Yogyakarta: Ar-ruz Media.

[12] M. Chan, SamdanTuti T. Sam. 2007. Educational Policy of the Regional Autonomy Era. Jakarta: PT Raja Grafindo Persada.

[13] Mardapi, Djemari. 2009."Evaluation of the Implementation of
National Standards-Based Elementary School Final Examination". Journal of Educational Research and Evaluation. Vol. 13. No. 2: p. 227-245.

[14] Milwan. 2018. Implementation of Government Policies in the Implementation of the Nine-Year Compulsory Basic Education Program in the City of Serang, Banten Province. Dissertation of IPDN Jatinagor.

[15] Mulyasa. 2014. Development and Implementation of the 2013 Curriculum. Bandung: Remaja Rosdakarya.

[16] Nugroho, Rian. 2003. Public Policy, formulation, implementation and evaluation. Jakarta: Media Komputindo.

[17] National Education Standards Ministry of National Education. Ministry of Education, 2004. Curriculum Based On Indonesian Language Subjects, Jakarta: Ministry of Education.

[18] Sugiyono. 2012. Qualitative, Quantitative Research Methods, and $R \& D$. Bandung: Alfabeta.

[19] Winarno, Budi. 2002. Theory and Process of Public Policy. Yogyakarta: Media press.

[20] Yasin, Muhammad. Quality Management in Educational Institutions with Achievement (Multi-Site Study of Madrasah Aliyah Public of 3 Kediri and Ar-Risalah Lirboyo Kediri High School). Dissertation of UIN Sunan Ampel Surabaya. 